\title{
RELATIONSHIP BETWEEN LIFESTYLE AND NUTRITIONAL STATUS AMONG ADOLESCENT
}

\author{
Hajnalka F. Požar ${ }^{1}$, Čaba F. Požar ${ }^{2}$ \\ ${ }^{1}$ Preschool Teacher and Sport Trainer High school in Subotica, Serbia \\ ${ }^{2}$ Technical School "Ivan Saric" Subotica, Serbia
}

\begin{abstract}
To prevent excess weight, the eating habits and lifestyle among adolescence arouse great interest in public health. The aim of this study is to analyze the lifestyle and nutritional status of this age, also to determine the difference between the habits of the students that attend the Medical and Technical school and to find out that knowing about the importance of a healthy lifestyle would have an effect on everyday habits.

The research was conducted as a cross-sectional study in a Medical school and a Technical school in Vojvodina. The research instrument was a questionnaire, which is anonymous and voluntary, filled out by 209 students, aged 14-18 years. Analysis of the data was analyzed by the statistical package SPSS. We used descriptive statistics and statistical significance between the two schools was tested using the Pearson $\chi 2$ test. Students of the technical school don't think about health, but they are physically more active. They have a higher percentage of overweight students (18\%). The students of the Medical school are thinking about health, physically less active, and have a higher percentage of underweight students (10\%). With appearance is satisfied with $44 \%$ of respondents. One-third believes that they have overweight and should lose a weight. The knowledge about the importance a healthy lifestyle in students of medical school affect consciousness in selecting foods, the desire to control their own weight, but does not influence to the regular physical activity.
\end{abstract}

Key words: EXERCISE / DIET / HEALTH / FOOD

\section{INTRODUCTION}

In the world and also here the problems of improper diet and physical inactivity in high school are present.Inadequate nutrition of young people seriously compromises their physical and mental development, reduces learning capacity and worsens eating habits that affect the prevalence of disease, not only in adolescence but also in adulthood. As a result of inadequate nutrition, being overweight and obesity can be found in $20-30 \%$ of children and adolescents in Europe (WHO, 2004). Most worrying is the fact that obese children remain obese in adulthood, and are prone to and often suffer from non-contagious chronic diseases (cardiovascular disease, cancer, diabetes) these are responsible for $86 \%$ of deaths and $77 \%$ of diseases in Europe (Ilić, 2010). Certain dietary changes and physical activity can prevent the cases of cardiovascular diseases and diabetes up to 60\% (Despotović, Ilić, Irgutinović \& Marković, 2013).

A healthy lifestyle is most commonly defined as engaging in physical exercise, sports and recreation, and active lifestyle defined by the quantity of exercise. However, lifestyle is a multidimensional measures of behavior, and can not be defined only by physical activity, because it was determined by other behaviors that are associated with health, especially healthy diet (Markus, 2012). Proper diet and regular physical activity are the basis of a healthy lifestyle, these are behaviors that improve health, and as such should be adopted at a young age (World Health Organization, 2005).

However, the entire system of nourishment in schools are not based on the principles of proper nutrition, instead it is left to the economic interests of individuals. Everything that is offered to young 
people in the immediate vicinity of the school is far from what would be a healthy meal at school (Bogar \& Kosić-Bibić, 2013). It is in adolescence, that young people consume more food outside the home, usually irregularly, they tend to skip meals, usually breakfast. "Fast food" meals are frequent outside the home, a lot of snacking between meals, drinking sweetened drinks, eating sandwiches as alternatives for school lunches. Such a diet is poor in fruits and vegetables, as well as high quality sources of protein which leads to deficiencies such as diseases or excessive energy intake. Many adolescents are unhappy with their appearance, and adolescence is also a period when young people begin to go on diets (Ilić, 2010; Cvijović, 2011).

Cultural influences on physical activity are great. Time for rest and work is increasingly carried out in inactivity, because children while watching television, playing video games, spending time on the computer, using means of transport only moving from one sitting position to another (Lešović, 2014).

The importance of health education and learning about proper nutrition and the positive effects of physical activity have been recognized by the education system. Although it has not been integrated into the educational plan of every elementary and high school, in medical schools thanks to the specificity of subject (such as Hygiene with health upbringing during the $2^{\text {nd }}$ year, Health Care internal and surgical patients during the $3^{\text {rd }}$ and $4^{\text {th }}$ year and Medical biochemistry during the $4^{\text {th }}$ year of schooling) it is mostly learned, so the students of the medical are better informed in comparison to other schools (The curriculum for the field work: Health and social services).

The goal of this paper is to examine the lifestyle among adolescent, to examine the difference in lifestyles of students attending the medical and technical school, to discover the extent to which knowledge about the importance of proper nutrition and physical activity affects the way of life.

The specific objectives of the research was to determine the nutritional status by using body mass index, and to discover what is the opinion of high school students on their own weight and whether they think about their health when choosing a diet.

The main hypothesis is that a larger number of students feed incorrectly, which results in increased body weight and dissatisfaction with their own body weight. The specific hypothesis is that students at medical schools pay more attention to choosing healthy foods and to regularly engage in physical activity as a result of a specific curriculum, as well as detailed knowledge about certain diseases and thereof their prevention.

\section{METHODS}

\section{The sample of respondents}

The survey was conducted as a cross-sectional study in which 119 (56,9\%)students participated from the Medical high school "7 April" in Novi Sad (nursing course), 44 male (37,0\%) and 75 female $(63,0 \%)$, and $90(43,1 \%)$ students from the Technical high school "Ivan Sarić" in Subotica (electric technician courses), 63 male (70,0\%) and 27 female (30,0\%), students aged 14- 18 years.

This study included 107 (51,2\%) male, and 102 $(48,8 \%)$ female subjects, of the total 209 . The respondents were from different parts of Vojvodina (Serbia), the larger percentages were from Novi Sad (30\%) and Subotica (20\%), and the surrounding villages (4\%).

\section{The sample of variables and instruments}

Data was obtained by interviewing. The survey was conducted during the school year of 2015/16., with the participation of. The survey was completely anonymous, the students filled it out voluntarily. To share the survey, the written consent of the school directors was obtained.

For research was used a questionnaire (Ilić, 2010; Despotović, Ilić, Irgutinović \& Marković, 2013), which in addition to general demographic data, contains questions about the anthropometric parameters, the frequency of physical activity (1. Once a day 2 . Two or three times a week, 3 . Once a week, 4 . Less than once a week 5 . Never), the thinking about health and holding diet (1. No, 2. No, but I should, 3. No, because I need to gain weight, 4 . Yes), and the attitude towards own body (1. Extremly too thin, 2. Too thin, 3. Good body weight 4. A little fat, 5. Extremly overweight)

\section{Data processing}

The analysis was done in SPSS 20.0 software package. For statistical analysis of the data descriptive methods and non-parametric analysis, statistical significance between the two schools and gender were tested using the method of cross tables and Pearson's $\chi 2$ test (Chi-square test). 


\section{RESULTS}

In Table 1, 2 and 3 are shown, the basic descriptive mass index (BMI) of respondent by sex and age. In parameters age, body weight, body height, and body

Figure 1 is shown the structure by sex and age.

Table 1. Anthropometric characteristics of the study participants

\begin{tabular}{|c|c|c|c|}
\hline Parameters & $\overline{\mathbf{x}} \pm \mathrm{SD}$ & Std. Error & Range \\
\hline Age (years) & $16,22 \pm 1,11$ & 0,074 & $14-18$ \\
\hline Weight (kg) & $65,49 \pm 11,80$ & 0,816 & 43-100 \\
\hline Height $(\mathrm{cm})$ & $179,60 \pm 110,53$ & 0,600 & $154-197$ \\
\hline $\begin{array}{l}\text { Body mass index } \\
\left(\mathrm{kg} / \mathrm{m}^{2}\right)\end{array}$ & $22,02 \pm 3,017$ & $\underline{0,2087}$ & $\underline{14,5-32,7}$ \\
\hline
\end{tabular}

Table 2. The descriptive parameters of the subjects according to sex

\begin{tabular}{|c|c|c|c|c|}
\hline \multirow[t]{2}{*}{ Parameters } & \multicolumn{2}{|c|}{ Boys } & \multicolumn{2}{|l|}{ Girls } \\
\hline & $\underline{\bar{x}} \pm$ SD & Range & $\underline{\bar{x}} \pm \mathrm{SD}$ & Range \\
\hline Age (years) & $16.11 \pm 1.20$ & $14-19$ & $16.32 \pm 1.10$ & 14-19 \\
\hline Weight (kg) & $71.18 \pm 11.33$ & $45-100$ & $59.53 \pm 9.05$ & 43-90 \\
\hline Height $(\mathrm{cm})$ & $177.56 \pm 7.18$ & $160-197$ & $166.17 \pm 5.81$ & $154-180$ \\
\hline Body mass index $\left(\mathrm{kg} / \mathrm{m}^{2}\right)$ & $22.47 \pm 3.02$ & $16.9-30.9$ & $21.54 \pm 2.95$ & $14.5-32.7$ \\
\hline
\end{tabular}

Table 3. The descriptive parameters of the subjects according to the age

\begin{tabular}{|c|c|c|c|c|c|c|}
\hline Parameters & $\begin{array}{l}14 \text { год. } \\
\bar{x} \pm \mathrm{SD} \\
\end{array}$ & $\begin{array}{l}15 \text { год. } \\
\bar{x} \pm \text { SD }\end{array}$ & $\begin{array}{c}16 \text { год. } \\
\bar{x} \pm \mathrm{SD}\end{array}$ & $\begin{array}{l}17 \text { год. } \\
\bar{x} \pm \mathrm{SD}\end{array}$ & $\begin{array}{c}18 \text { год. } \\
\overline{\mathbf{x}} \pm \mathrm{SD} \\
\end{array}$ & $\begin{array}{l}19 \text { год. } \\
\bar{x} \pm \mathrm{SD}\end{array}$ \\
\hline Weight (kg) & $56.67 \pm 6.12$ & $65.96 \pm 11.65$ & $66.60 \pm 13.33$ & $66.16 \pm 10.77$ & $61.39 \pm 9.63$ & $68.75 \pm 15.74$ \\
\hline Range & $50-68$ & 43-100 & 44-100 & $45-90$ & 48-80 & $52-90$ \\
\hline Weight (kg) & $170.67 \pm 11.08$ & $171.53 \pm 7.89$ & $173.52 \pm 8.46$ & $172.07 \pm 8.95$ & $169.26 \pm 9.55$ & $171.50 \pm 11.12$ \\
\hline Range & $159-188$ & 155-193 & 154-197 & $159-196$ & 155-186 & 156-182 \\
\hline Body mass index & $19.47 \pm 1.15$ & $22.36 \pm 3.19$ & $21.98 \pm 3.37$ & $22.16 \pm 2.66$ & $21.38 \pm 2.50$ & $23.13 \pm 2.78$ \\
\hline Range & $17.4-20.7$ & $15.4-29.2$ & $14.5-32.7$ & $16.9-31.1$ & $17.7-28.6$ & $21.3-27.2$ \\
\hline
\end{tabular}

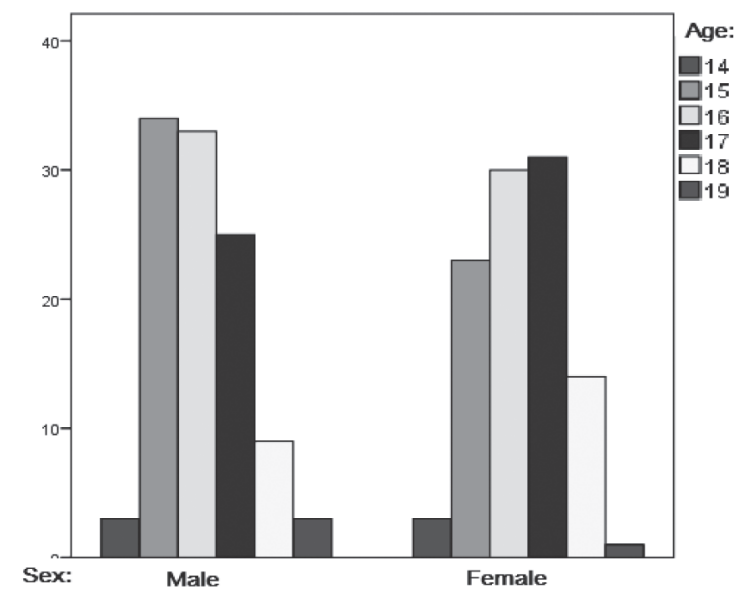

Fig. 1. Structure of respondents by sex and age 
According to this research results of our students are $8.6 \%$ underweight (BMI 18.5), $7.5 \%$ of men and $9.8 \%$ of women, $10 \%$ of medical students and $6 \%$ of technical school students.

Normal weight (BMI 18.5-24.9) had 74.6\% of students, $71 \%$ of men and $78.4 \%$ of girls. In the higher percentage of technical school students (75.5\%).
Overweight (BMI 25-29.9) was $15.3 \%$ of students, $20.5 \%$ of men and $9.8 \%$ of girls ( $p=0.024)$. There is no difference in the incidence of overweight and schools. Obese (BMI 30 and over) was $1.4 \%$ of the students, $0.9 \%$ of men and $1.9 \%$ women, who were identified as students of technical school. Distribution of BMI by age is shown in Figure 2.

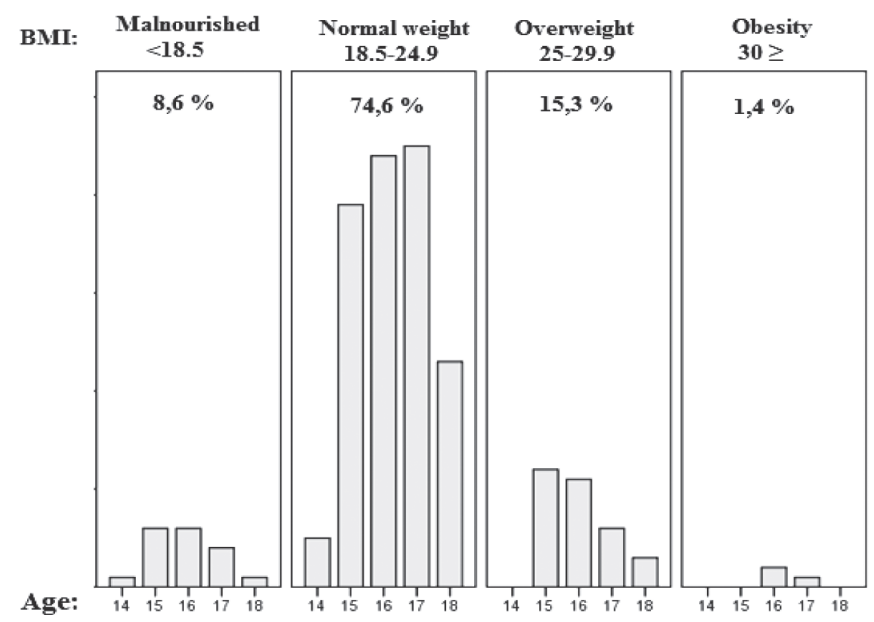

Fig.2. Body mass index $\left(\mathrm{kg} / \mathrm{m}^{2}\right)$ distribution by age

When choosing food for breakfast healthiness is still considered by $30.1 \%$ of students. More frequently by medical students (32.8\%) than technical school (26.7\%) students. Sometimes does it $49.3 \%$ of the respondents, more women (51\%). While $20 \%$ of the respondents never thinks about healthiness at breakfast, more men and students of technical schools (41\%).

At lunch $48.3 \%$ of the children are considering healthiness, more students of medicine (53.8\%) than technical school (41\%). More girls (52\%), than boys (45\%).

When choosing foods for dinner healthiness is still considered by $40 \%$ of the students, more often by girls, and by students of the medical school (47\%) than the technical school students (31\%), with statistically correlation $p=0.039$. On average $40 \%$ of respondents occasionally thinks about healthiness and their choice of food for lunch and dinner.

Physical activity daily is done by $32.5 \%$ of children, $45 \%$ of boys and $20 \%$ girls $(\mathrm{p}=0.001)$. This includes $39 \%$ of students from the technical school $(p=0.038)$. Exercise $2-3$ times a week is done by $40 \%$ of them, mainly girls (44.9\%). Almost $15.3 \%$ exercises less than once a week or never trains (Figure 3).

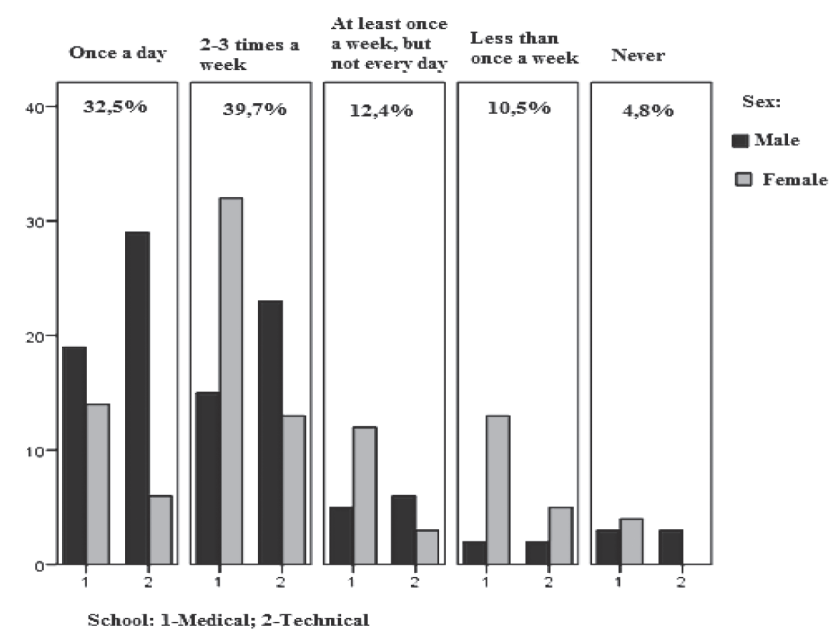

Fig.3. The frequency of physical activity by school and sex 
With their appearance $44 \%$ of respondents was satisfied, $57 \%$ of boys and $30 \%$ girls, with statistical significant correlation $\mathrm{p}=0.001$. One-third believes that is overweight ( $50 \%$ of girls and $19.6 \%$ of boys), and that they should lose weight (Figure 4). While $12.4 \%$ of respondents (19.6\% girls) already hold a diet, $15 \%$ of medical school students and $9 \%$ of technical school students.

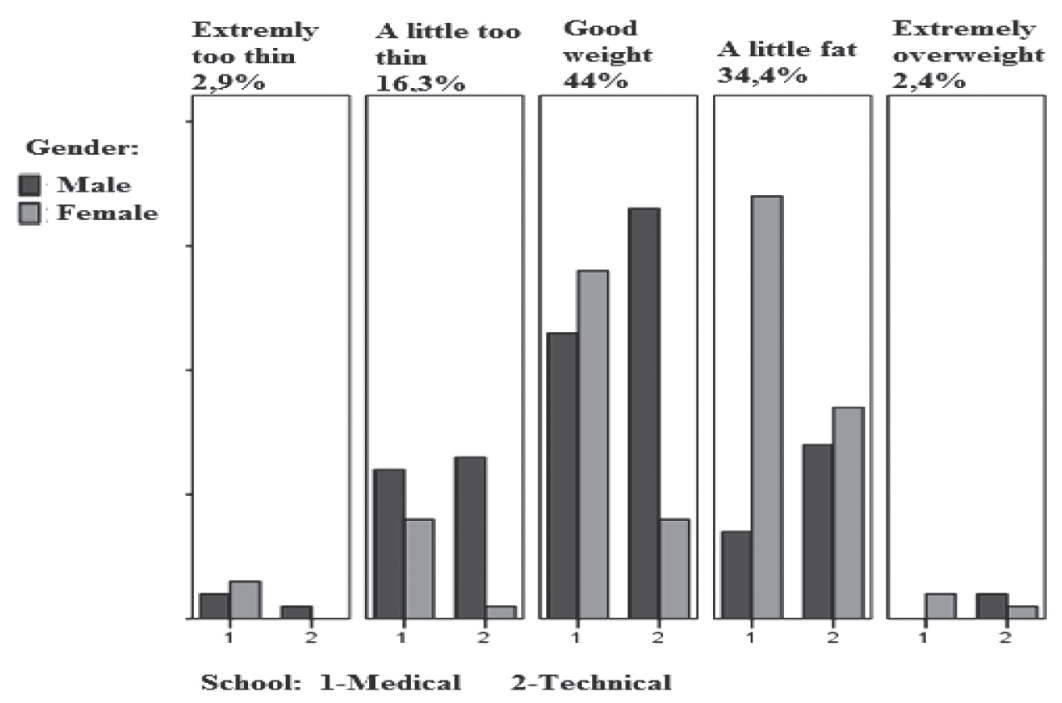

Fig.4. The attitude towards one's own body, by school and sex

Students that are overweight engage in physical activity 2-3 times a week (43.8\%) and daily (40.6\%), they are aware that they have excess weight, and that they should lose weight, and $28 \%$ are on a diet. It is positive that they recognize the importance of daily or at least regular physical activity, and thus attempt to reduce or maintain weight. Obese children are less physically active and exercise only once a week (66.7\%). Some of them they think should lose weight, while there are those who are satisfied with their current weight, however none of the obese children are holding a diet. There is a correlation between the position of one's own body weight and body mass index $(\mathrm{p}=0.000)$, and also with dieting $(\mathrm{p}=0.032)$ (Table 4$)$. 
Table 4. Relations between body mass index and physical activity, dieting and attitude towards their own body

\begin{tabular}{|c|c|c|c|c|c|}
\hline Body Mass Index & $\begin{array}{c}\text { Underweight } \mathrm{n} \\
(\%)\end{array}$ & $\begin{array}{c}\text { Normal } \\
\text { n }(\%)\end{array}$ & $\begin{array}{c}\text { Overweight } \mathrm{n} \\
(\%)\end{array}$ & $\begin{array}{l}\text { Obese } \\
\mathrm{n}(\%)\end{array}$ & $\begin{array}{l}\text { Total } \\
\mathrm{n}(\%)\end{array}$ \\
\hline Physical activity & & & $p=0.21$ & & \\
\hline Once a day & $3(16.7)$ & $51(32.7)$ & $13(40.6)$ & $1(33.3)$ & $68(32.5)$ \\
\hline 2-3 times a week & $9(50.0)$ & $60(38.5)$ & $14(43.8)$ & $0(0.0)$ & $83(39.7)$ \\
\hline At least once a week & $3(16.7)$ & $19(12.2)$ & $2(6.2)$ & $2(66.7)$ & $26(112.4)$ \\
\hline Least once a week & $2(11.1)$ & $19(12.2)$ & $1(3.1)$ & $0(0.0)$ & $22(10.5)$ \\
\hline Never & $1(5.6)$ & $7(4.5)$ & $2(6.2)$ & $0(0.0)$ & $10(4.8)$ \\
\hline Diet & & & $\mathbf{p}=\mathbf{0 . 0 3}$ * & & \\
\hline No,I am satisfied with my weight & $11(61.1)$ & $74(47.4)$ & $6(18.8)$ & $1(33.3)$ & $92(44.0)$ \\
\hline No, but I should to lose weight & $1(5.6)$ & $44(28.2)$ & $16(50.0)$ & $2(66.7)$ & $63(30.1)$ \\
\hline No, because I need to gain weight & $6(33.3)$ & $21(13.5)$ & $1(3.1)$ & $0(0.0)$ & $28(13.4)$ \\
\hline Yes & $0(0.0)$ & $17(10.9)$ & $9(28.1)$ & $0(0.0)$ & $26(12.4)$ \\
\hline Attitude towards one's own body & & & $\mathbf{p}=0.00 * *$ & & \\
\hline Extremely thin & $2(11.1)$ & $3(1.9)$ & $1(3.1)$ & $0(0.0)$ & $6(2.9)$ \\
\hline Something too thin & $6(33.3)$ & $27(17.3)$ & $1(3.1)$ & $0(0.0)$ & $34(16.3)$ \\
\hline Pretty good weight & $9(50.0)$ & $75(48.1)$ & $7(21.9)$ & $1(33.3)$ & $92(44.0)$ \\
\hline Slightly thick & $1(5.6)$ & $49(31.4)$ & $21(65.6)$ & $1(33.3)$ & 7234.4) \\
\hline Extremely overweight & $0(0.0)$ & $2(1.3)$ & $2(6.2)$ & $1(33.3)$ & $5(2.4)$ \\
\hline
\end{tabular}

${ }^{*}$ Statistical correlation is significant at the level $\mathrm{p} \leq 0.01 ;{ }^{\star}$ Statistical correlation is significant at the level $\mathrm{p} \leq 0.05$

\section{DISCUSSION}

According to the results of studies on the health of the population in Serbia in 2013, they registered an increase in the percentage of obese children (4.9\%) compared to 2006 (2.6\%). Also a significantly higher percentage of moderately obese (13.2\%) and obese $(7.5 \%)$ children were recorded among children aged 11-14 years (Boričić, et al., 2014).

According to our results, in the sample we are identified $16.7 \%$ overweight and obese children, who are a warning about the low quality of their diets and physical inactivity. However, as we don't found an extremely large number of excess weights, we reject the basic hypothesis.

The status of nourishment in our study is somewhat more favorable in comparison to the survey conducted in Bor (central Serbia) among primary school pupils in 2011 (Stanković \& Mihajlović, 2011), when they found that normal body weight had $81 \%$ of the girls and 3\% were underweight, and $16 \%$ had excess weight (in our study, we found $9.8 \%$ underweight and $11.76 \%$ of girls are overweight). $68 \%$ of boys had normal weight, $7 \%$ was underweight and $25 \%$ were overweight (in our study we found $7.48 \%$ malnourished boys and $21.49 \%$ with excess weight).

Observing the schools, we found that students of technical school have a larger percentage of daily physical activity. Here we identified $17.8 \%$ overweight and $6.6 \%$ underweight students. While, students of the Medical school have a lower percentage and rarely engage in physical activity. Here we identified 15.9\% of overweight and $10 \%$ of malnourished students.

As for the differences between men and women, we noticed that men are physically more active, mainly satisfied with their weight, only $5 \%$ hold a diet. Girls, however, are less frequently (2-3 times per week) engaged in physical activity. Almost 50\% 
of girls considered themselves overweight, and 20\% already hold a diet.

Broken down by age, we identified among 15 year olds $21 \%$, among 16 year olds $20.7 \%$, among 17 year olds $12.5 \%$ and among 18 year olds $11.1 \%$ of respondents with excessive weight. Obviously, the percentage of excessive weight respondents declines with age.

Nutritional status of adolescents is of great interest to public health, in terms of prevention of diseases associated with obesity. The effects of obesity in young people can lead to long-term health problems. It is important to emphasize that physical activity in childhood and adolescence should be constantly stimulated, in which the biggest role has physical education teachers.

The teacher of physical education, through its activities in the school and outside the school, in sports clubs, plays an important role in physical and mental development of children with effect on the personality of young people, directly assisting its formation and development. The teacher makes the students develop skills in accordance with the talent, potential predisposition, influence at the same time educational of their personality (Krasniqi, et al., 2008).

Several studies confirm this fact. Thus, for example, in India examined the effect of daily physical activity beside of regular school hours on body composition in obese men aged 9-15 years (Apte \& Rao, 2013). The intervention involved the 5 sessions per week, beside school hours for a period of 50 minutes. After one year, assessed the impact of physical activity on reducing obesity. They found that participants show a significant reduction in body fat $(1.0 \%)$, reduction of skinfold thickness, too, there was a significant reduction in indicators of central obesity - waist circumference (from 1.8 to $1.1 \mathrm{~cm}$ ) with respect to their original measurement. This indicates that the potential benefits of 50 minutes daily physical activity justify the introduction in the curriculum of schools, for better health adolecenata.

However, the benefits of regular physical activity could be reach up within the current school program, modification of content. It's been proven in Brazil, where nearly 400 subjects aged 15-17 years involved in research on the impact of physical activity on body composition (Farias, Gonçalves, Morcillo, Guerra-Júnior, \& Amancio 2015). The study group is subjected to a specific program of physical activity during the regular physical education classes (aerobic activity, muscle strength exercises, running, jump- ing, sports games and stretching) while the control group attended a conventional program of physical education (sports games through exercise, gymnastics, base of sports). Both groups had a regular two hours of physical education per week, during the school year. The results are reported positive effects of programmed physical activity in the control group (p 0.001) in both sexes, reducing the percentage of fat (mean difference $=-5.58 \%$ ) and waist circumference $(-2.33 \mathrm{~cm})$, and an increase in clean weight $(+2.05$ $\mathrm{kg}$ ), while the opposite was observed in the control group. This points to the role of physical education teachers, as the just choice of physical activity can achieve reduction of body weight and contribute to the health of adolescents in the context of regular teaching physical education classes.

Also examined was the impact of programmed and self-selected physical activity on physical fitness of adolescents (Neto et al., 2014). One group of students performed physical activity according to their own rhythm in the following sports: basketball, volleyball, handball, football and swimming. While another group of programmed physical activity is performs specified conditional exercise. Training for both groups lasted 60 minutes. Intervention with programmed physical activity showed more changes in physical abilities, the cardiorespiratory state and strength of the lower and upper extremities.

According to previously analyzed, the greatest potential is found in the decision that the state recognizes the importance of prevention hronical noncommunicable diseases through adequate nutrition and regular physical activity from an early age. School sport should contribute to improving public health, but in the analysis of this problem is usually stated that there are a small number of sports sections, which operate non-systematic. Today the little number of school has a regularly organized sport sections, so sport in schools regularly engaged in only $3-5 \%$ of the students, and one of the main problems is the existence only 2 hours of physical education per week (Provincial Secretariat for Sports, Vojvodina, Serbia, 2007)

However, as it was submitted in the "Strategies for the development of sport school in Vojvodina for the period 2013-2017" highlights, daily physical activity should be incorporated into the curriculum, while this is not achieved, the emphasis should be put to sport in schools should is available as an optional subject, or by providing a variety of free sections of sport within the the school. 
Also, more emphasis should be placed on school meals. The good and bad habits acquired in childhood remain until the end of life, and improper diet can have significant consequences. The development of eating habits of school children most affected by the parents, but we must point out the impact of the school on the formation of the child's personality and adopting healthy eating habits and behavior.

Special significance have a school meal, because children six or more hours spend in school, and during that time consumed largely unhealthy meals, snacks, fast food and soft drinks, with high fat and concentrated carbohydrates, which can cause overweight (Janković, 2003). Legal provision of adequate, healthy food in the school cafeteria, student dormitories could significantly reduce diseases associated with inadequate nutrition.

\section{CONCLUSION}

Only a third of respondents are engaged daily physical activity. Differences in lifestyle among students of medical and technical schools, are reflected

\section{REFERENCES}

1. Apte, P.P., \& Rao, S. (2013). Effects of after school physical activity intervention to reduce obesity among Indian adolescent boys. Current Research in Nutrition and Food Science Journal, 1(1): 93-101.

2. Bogar, J., Kosić-Bibić, N. (2013). Ishrana po meri srednjoškolaca. [Nutrition tailored for secondary school, In Croatian]. Institute of Public Health of Subotica. Hrvatski časopis za javno zdravstvo, 9(35), 95-102.

3. Boričić, K., Vasić, M., Grozdanov, J., Gudelj-Rakić, J., et al. (2014). Rezultati istraživanja zdravlja stanovništva Srbije, 2013 godina. [The results of studies on the health of the population in Serbia, 2013. In Serbian]. The Ministry of Health of the Republic of Serbia and the Institute of Public Health of Serbia "Dr Milan Jovanović Batut”, Official Gazette, Beograd.

4. Cvijović, M. (2011). Značaj i mogućnosti nutritivnog programa "Čigotica" u usvajanju zdravog načina ishrane. [The importance and possibilities of nutrition program "Čigotica" in adopting a healthy diet, in Serbian]. Medical Gazette of the Special Hospital for Thyroid and Metabolical diseases Zlatibor 16(39), 120-123. primarily in the frequency of physical activity, which is present in higher percentage among students of technical schools and boys. In assessing the nutritional status we found more malnourished students between medical school, while in technical school more obese student. Mostly women believe that they have an excess weight, and the large number from the medical school is already hold uncontrolled diet. Mainly students from medical school think about their health when choosing food. Knowledge about the importance of proper nutrition and physical activity among medical school students affect consciousness in selecting foods, but does not affect regular physical activity. Apparently, the knowledge that nursing students receive in medical schools without practical advice and motivation is not enough to change lifestyle. This is a long process that needs to start at a young age. In addition to families, schools and teachers have a crucial role, promoting healthy lifestyles, the importance of regular activity and the possible consequences of obesity.

5. Despotović, M., Ilić, B., Igrutinović, Z., Marković, S. (2013). Stanje uhranjenosti dece predškolskog uzrasta. [Nutritional status of preschool children. In Serbian]. Medical Journal (Section Kragujevac) 47(2), 62-68.

6. Farias, E.S., Gonçalves, E.M., Morcillo, A.M., Guerra-Júnior, G., \& Amancio, O.M.S. (2015). Effects of programmed physical activity on body composition in post-pubertal schoolchildren. Jornal de Pediatria (Rio J), 91(2): 122-129.

7. Ilić, M. (2010). Navike u ishrani adolescenata u Zaječaru. [Adolescent nutrition habits in province of Zaječar. In Serbian]. Timočki medicinski glasnik, 35(3-4), 57-63.

8. Jankovič, S. (2003). Pedeset savjeta za zdravlje. [Fifty tips for health. In Croatian]. Croatian Institute for Public Health, Zagreb.

9. Krasniqi, F., Salihu, H. i Ahmeti, V. (2008). The teacher of physical education - support of physical health and personality of children and young people. Sport Science 1, (1):66-69.

10. Lešović, S. (2014). Centar za prevenciju i liječenje pretilosti u djece i adolescenata. [Center for the 
prevention and treatment of obesity in children and adolescents. In Croatian]. Paediatria Croatica, 58(Supl.1), 238-242.

11. Markuš, D. (2012). Konstrukcija ljestvice za mjerenje zdravog života srednješkolaca. [Construction of scale for measuring healthy lifestyle in high school. In Croatian]. 21 Summer School of Kinesiology, Croatian Republic.

12. Nastavni plan. Područje rada: Zdravstvo i socijalna zaštita. [Teaching plan. Area of work: Health and social services. Education profile: nurse technician, In Serbian].

13. Neto, C.F., Neto, G.R., Araújo, A.T., Sousa, M.S.C., Sousa, J.B.C., Batista, G.R., \& Reis, V.M.R. (2014). Can programmed or self-selected physical activity affect physical fitness of adolescents? Journal of Human Kinetics, 43, 125-130.

14. Provincial Secretariat for Sports and Youth. (2007). Izveštaj o stanju sporta u AP Vojvodine. [The report on the status of sport in the AP Vojvodina. In Serbian]. Novi Sad.
15. Stanković, J., Mihajlović, K. (2011).Ishrana učenika osmog razreda OŠ "Ljuba Nešić". [Nutrition of $8^{\text {th }}$ grade primary schoolers "Ljuba Nešić" students. In Serbian].Regional Center for talents in Bor, 1-12.

16. Provincial Secretariat for Sports and Youth. (2013). Strategija za razvoj sporta u AP Vojvodina $z a$ period 2013-2017. [The strategy for the development of sport in Vojvodina for the period 20132017. In Serbian]. Novi Sad.

17. World Health Organization Europe (2005). European strategy for child and adolescent health and development. Available from http://www. euro.who.int/__data/assets/pdf_file/0020/79400/ E87710.pdf (European)

18. World Health Organization Europe (2004). Food and health in Europe: a new basis for action. European series, No.96. Available from http:// www.who.int/nutrition/publications/Food_and_ health_Europe\%20_newbasis_for_\%20action.pdf (European)

\title{
VERHÄLTNIS ZWISCHEN LEBENSSTIL UND ERHÄHRUNGSZUSTAND BEI ADOLESZENTEN
}

\begin{abstract}
Zusammenfassung
Der Lebensstil von Adoleszenten weckt immer größeres Interesse im Sektor der öffentlichen Gesundheit in Bezug auf die Verhinderung von Übergewicht. Das Ziel der Arbeit war es, den Lebensstil dieser Altersgruppe zu erfassen und die Unterschiede zwischen den Lebensstilen von Schülern der Medizinischen und der Technischen Schule festzulegen. Die Untersuchung wurde als Querschnittstudie während des Schuljahres 2015/2016 in der Medizinischen Schule in Novi Sad und der Technischen Schule in Subotica durchgeführt. Das Instrument der Untersuchung war ein Fragebogen, der anoynm und auf freiwilliger Basis von 209 Schülern im Alter von 14 bis 18 Jahren ausgefüllt wurde. Die Analyse der Daten wurde mit einem SPSS-Paket durchgeführt. Es wurde eine deskriptive Statistik angewendet, die statistische Bedeutung zwischen den beiden Schulen und nach den Geschlechtern wurde mit Hilfe des Pearson Chi-Quadrat-Tests geprüft. Die Schüler der Technischen Schule sind körperlich aktiver, denken aber in einem niedrigerem Prozentsatz bei der Auswahl der Lebensmittel an ihre Gesundheit; unter ihnen litten 18\% an Übergewicht. Die Schüler der Medizinischen Schule denken bei der Auswahl der Lebensmittel in größerem Maße an ihre Gesundheit, sind aber körperlich weniger aktiv, was zu einem höheren Prozentsatz (10\%) an unterernährten Schülern führte. 44\% der Prüflinge sind mit ihrem Aussehen zufrieden. Ein Drittel der Schüler ist der Meinung, dass sie eine übermäßige Körpermasse haben und abnehmen müssen. Das Wissen von der Wichtigkeit eines gesunden Lebensstils beeinflusst bei Schülern der Medizinischen Schule das Bewusstsein bei der Auswahl von Lebensmitteln und den Wunsch, das eigene Gewicht zu kontrollieren, hat aber keinen Einfluss auf die Regelmäßigkeit von körperlichen Aktivitäten.
\end{abstract}

Schlüsselwörter: KÖRPERLICHE AKTIVITÄT / DIÄT / GESUNDHEIT / LEBENSMITTEL

Received: 05.02. 2017

Accepted: 17.11.2017 


\title{
ВЕЗА ИЗМЕБУ СТИЛА ЖИВОТА И СТАТУСА УХРАЊЕНОСТИ У ПОПУЛАЦИЈИ АДОЛЕСЦЕНАТА
}

\author{
Хајналка Ф. Пожар ${ }^{1}$, Чаба Ф. Пожар ${ }^{2}$ \\ ${ }^{1}$ Виша школа за васпитаче и спортске тренере, Суботица, Србија \\ ${ }^{2}$ Техничка школа „Иван Сарић“, Суботица, Србија
}

\begin{abstract}
Сажетак
Животни стил адолесцената изазива све веће интересовање у јавном здрављу у погледу спречавања гојазности. Циљ рада је био да сагледа стил живота овог узраста, и да утврди разлике у животним навикама између ученика медицинске и техничке школе. Истраживање је спроведено као студија пресека током школске 2015/16 године, у Медицинској школи у Новом Саду и Техничкој школи у Суботици. Инструмент истраживања је био анкетни упитник, које је анонимно и добровољно попунило 209 ђака, узраста 14-18 година. Анализа података је урађена СПСС пакетом. Коришћена је дескриптивна статистика, а статистичка значајност између две школе и по полу тестирана је помоћу Пирсоновог $\chi^{2}$ теста. Ученици техничке школе су физички активнији, али у мањем проценту размишљаљу о здрављу при одабиру намирница и међу њима је било 18\% гојазних. Ученици медицинске школе чешће размишљају о здрављу при одабиру намирница, међутим, физички су мање активни, и појавио се већи проценат (10\%) потхрањених ученика. Својим изгледом је задовољно 44\% испитаника. Једна трећина сматра да има прекомерну телесну масу, те да би требало да смршају. Знање о важности здравог начина живота код ученика медицинске школе утиче на свесност при одабиру намирница, на жељу да се контролише сопствена тежина, али не утиче и на редовност бављења физичком активношћу.
\end{abstract}

Кључне речи: ФИЗИЧКА АКТИВНОСТ / ДИЈЕТА / ЗДРАВЉЕ / НАМИРНИЦЕ

\section{УВОД}

У свету и код нас све су присутнији проблеми неправилне исхране и физичке неактивности адолесцената. Као резултат тога, прекомерна ухрањеност и гојазност може се наћи код 20-30\% деце и адолесцената у Европи (WHO, 2004). Највише забрињава чињеница да гојазна деца остају гојазна и у одраслом добу, те су склонија да раније и чешће оболе од хроничних незаразних болести (кардиоваскуларне болести, рак, дијабетес) које су одговорне за 86\% случајева смрти у Европи (Илић, 2010). Међутим, извесне промене у исхрани и физичка активност могу да спрече до $60 \%$ случајева дијабетеса и кардиоваскуларних обољења (Деспотовић, Илић, Игрутиновић, и Марковић, 2013).

Здрав стил живота се начешће дефинише као бављење телесним вежбањем, спортом и рекреацијом, док је активан стил живота дефинисан и количином кретања. Међутим, животни стил је вишедимензионална мера понашања, и не може бити дефинисана искључиво физичком активношћу, већ је одређен и другим понашањима који су повезани са здрављем, пре свега здравом исхраном (Markuš, 2012). Правилна исхрана и редовна физичка активност чине основ здравог стила живота, то су понашања која унапређују здравље, и као таква треба да буду усвојена у млађем животном добу (WHO, 2005).

Међутим, целокупан систем исхране у школама није заснован на принципима правилне исхране, већ је препуштен економским интересима појединаца. Све оно што се младима нуди у непосредној близини школа је далеко од онога што би био здрав оброк у школи (Bogar \& Kosić-Bibić, 2013). Управо у адолесцентном периоду млади се више хране ван куће, најчешће нередовно, често прескачу оброке. Између оброка много 
конзумирају различите грицклице, пију напитке са високим нивоом шећера и једу сендвиче као алтернативу за школски ручак. Овакав начин исхране, сиромашан у воћу и поврћу, као и квалитетним изворима протеина доводи до болести дефицита или прекомерног енергетског уноса. Многи су незадовољни својим изгледом, те је адолесценција уједно и период када млади почињу са држањем дијета (Илић, 2010; Цвијовић, 2011).

Културолошки утицаји на навике у физичкој активности су велики. Деца су посебно подложна утицају телевизије и интернета, док култура и образовни систем нуде мало алтернативе. Време одмора и рада све се више проводи у мировању, јер се деца проводећи време уз телевизију и рачунаре, користећи превозна средства, премештају из једног седећег положаја у други (Lešović, 2014). Важност здравственог васпитања о принципима правилне исхране и позитивним ефектима физичке активности је препозната од стране образовног система. Иако још није имплементиран у наставни план свих школа, у медицинским школама захваљујући специфичностима одређених стручних предмета (као што су Хигијена са здравственим васпитањем током 2. године, Здравствена нега интернистичких и хируршких болесника током 3. и 4. године, као и Медицинска биохемија током 4. године школовања), ученици су упознати са тим принципима, те се оправдано може пертпоставити да су они боље информисани у односу на друге школе (Наставни план за подручје рада: Здравство и социјална заштита).

Општи циљ истраживања је био да се утврди животни стил ученика средње школе, затим да се укаже на разлике у начину живота ученика медицинске и техничке школе, да би се испитало у којој мери знање о значају правилне исхране и физичке активности утиче на стил живота. Специфични циљеви су били: да се утврди статус ухрањености помоћу индекса телесне масе код различитог узраста ученика, да се испита мишљење ученика о сопственој телесној маси, те да ли ученици размишљају о здрављу при избору намирница.

Основна претпоставка је била да се већина испитаника храни неправилно, што за последицу може да има повишену телесну масу и незадовољство сопственом телесном масом. Такође, претпоставња се да ученици медицинских школа, у односу на ученике техничких школа, више пажње посвећују избору здраве хране и да се редовније баве физичком активношћу што је резултат одређеног знања о хроничним незаразним болестима и њиховом спречавању.

\section{МЕТОД}

\section{Узорак испитаника}

Истраживање је спроведено као студија пресека у коме је учествовало 119 ученика (56,9\%) Медицинске школе “7.април” у Новом Саду (смер: Медицинска сестра-техничар), 44 дечака $(37,0 \%)$ и 75 девојчица (63,0\%), и 90 ученика (43,1 \%) Техничке школе “Иван Сарић” у Суботици (смер: Електро и Сабраћајни техничар), 63 дечака (70,0\%) и 27 девојчица (30,0\%), узраста од 14 до 18 година. Укупно, 107 (51.2\%) мушких и 102 женска (48.8\%) испитаника. Испитаници су били заступљени из разних крајева Војводине и то: Темерин (39\%), Суботица $(29 \%)$, Нови Сад (27\%) и околна насеља (4\%).

\section{Узорак варијабли и инструменти}

Подаци су добијени анкетирањем које је спроведено током школске 2015/16. године. Анкета је била анонимна, ученици су је попуњавали добровољно. За поделу анкета добијена је писана сагласност директора школа.

Коришћен је нестандардизовани анкетни упитник из познатих студија које су се бавиле сличном проблематиком (Илић, 2010; Деспотовић, Илић, Игрутиновић \& Марковић, 2013), и који поред општих демографских података и антропометријских параметара садржи четири питања која се односе на: начин исхране у смислу редовности узимања оброка, учесталост физичке активности (1. Једном дневно 2. Два до три пута недељно 3. Једном недељно 4. Ређе од једном недељно 5. Никада), држање дијете (1. Не 2. Не, али би требаo/ ла 3. Не, јер се требам удебљати 4. Да), став према сопственом телу (1. Изразито премршав/а 2. Heшто премршав/а 3. Прилично добре телесне масе 4. Прекомерно ухрањено/а 5. Гојазно/а).

\section{Обрада података}

Обрада података је урађена софтверским пакетом СПСС 20.0. За статистичку обраду коришћене су методе дескриптивне анализе и метода укрштених табела. Статистичка значајност разлика између две школе и по полу тестирана је уз примену Пирсоновог Хи квадрат $\left(\chi^{2}\right)$ теста. 


\section{РЕЗУЛТАТИ}

У табели 1,2 и 3 су приказани основни дескриптивни параметри узраста, телесне масе, те- лесне висине и индекса телесне масе (БМИ) испитаника укупно, према полу и према старости. На слици 1. дата је структура испитаника по полу и старости.

Табела 1. Дескриптивни параметри испитаника

\begin{tabular}{lccc}
\hline Парамерти & М \pm СД & CE & Опсег \\
\hline Узраст (године) & $16.22 \pm 1.11$ & 0.07 & $14-18$ \\
Телесна маса $(\mathrm{kg})$ & $65.49 \pm 11.80$ & 0.82 & $43-100$ \\
Телесна висина $(\mathrm{cm})$ & $172.0 \pm 8.68$ & 0.60 & $154-197$ \\
БМИ $\left(\mathrm{kg} / \mathrm{m}^{2}\right)$ & $22.02 \pm 3.017$ & 0.21 & $14.5-32.7$ \\
\hline
\end{tabular}

Табела 2. Дескриптивни параметри испитаника према полу

\begin{tabular}{llcccc}
\hline Парамерти & \multicolumn{2}{c}{ Дечаци } & & \multicolumn{2}{c}{ Девојчице } \\
\cline { 2 - 3 } Узраст (године) & $16.11 \pm 1.20$ & $14-19$ & & $16.32 \pm 1.10$ & $14-19$ \\
Телесна маса $(\mathrm{kg})$ & $71.18 \pm 11.33$ & $45-100$ & & $59.53 \pm 9.05$ & $43-90$ \\
Телесна висина $(\mathrm{cm})$ & $177.56 \pm 7.18$ & $160-197$ & & $166.17 \pm 5.81$ & $154-180$ \\
БМИ $\left(\mathrm{kg} / \mathrm{m}^{2}\right)$ & $22.47 \pm 3.02$ & $16.9-30.9$ & & $21.54 \pm 2.95$ & $14.5-32.7$ \\
\hline
\end{tabular}

Табела 3. Дескриптивни параметри испитаника према узрасту

\begin{tabular}{|c|c|c|c|c|c|c|}
\hline Параметри & $\begin{array}{l}14 \text { год. } \\
\text { М土СД }\end{array}$ & $\begin{array}{l}15 \text { год. } \\
\text { М土СД }\end{array}$ & $\begin{array}{c}16 \text { год. } \\
\text { М土СД }\end{array}$ & $\begin{array}{l}17 \text { год. } \\
\text { М土СД }\end{array}$ & $\begin{array}{c}18 \text { год. } \\
\text { М土СД }\end{array}$ & $\begin{array}{c}19 \text { год. } \\
\text { М土СД }\end{array}$ \\
\hline Телесна маса (kg) & $56.67 \pm 6.12$ & $65.96 \pm 11.65$ & $66.60 \pm 13.33$ & $66.16 \pm 10.77$ & $61.39 \pm 9.63$ & $68.75 \pm 15.74$ \\
\hline Опсег & $50-68$ & 43-100 & 44-100 & $45-90$ & 48-80 & $52-90$ \\
\hline Телесна висина $(\mathrm{cm})$ & $170.67 \pm 11.08$ & $171.53 \pm 7.89$ & $173.52 \pm 8.46$ & $172.07 \pm 8.95$ & $169.26 \pm 9.55$ & $171.50 \pm 11.12$ \\
\hline Опсег & $159-188$ & 155-193 & $154-197$ & $159-196$ & 155-186 & 156-182 \\
\hline БМИ $\left(\mathrm{kg} / \mathrm{m}^{2}\right)$ & $19.47 \pm 1.15$ & $22.36 \pm 3.19$ & $21.98 \pm 3.37$ & $22.16 \pm 2.66$ & $21.38 \pm 2.50$ & $23.13 \pm 2.78$ \\
\hline Опсег & $17.4-20.7$ & $15.4-29.2$ & $14.5-32.7$ & $16.9-31.1$ & 17.7-28.6 & $21.3-27.2$ \\
\hline
\end{tabular}

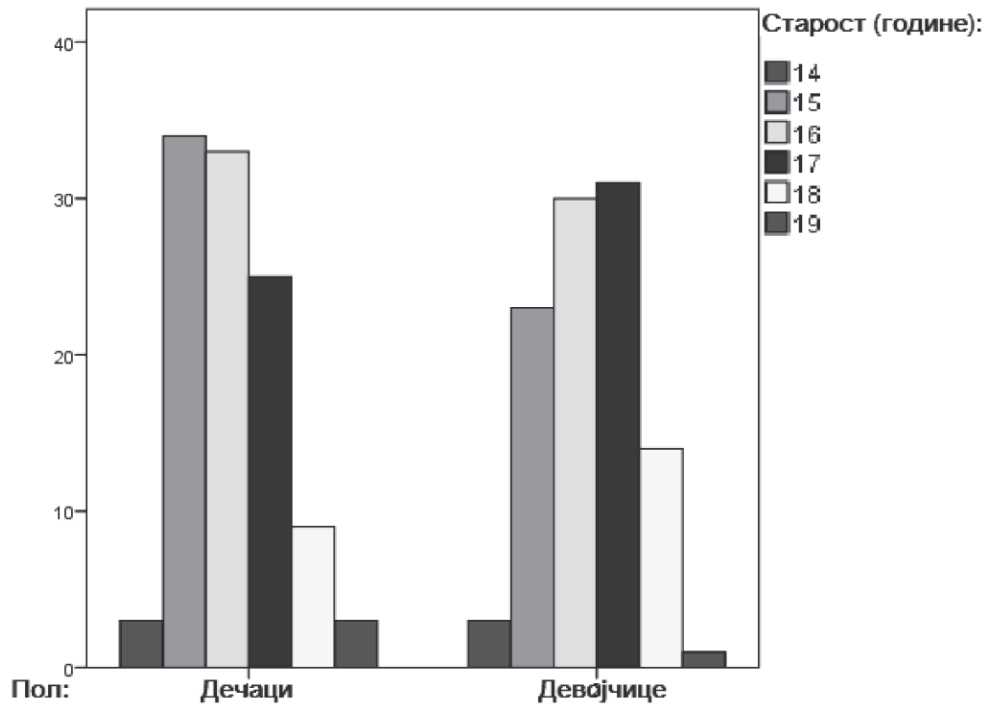

Слика 1. Испитаници по полу и старости 
Недовољно је ухрањено 8.6\% ученика (БМИ 18.5), $7.48 \%$ мушког и $9.80 \%$ женског пола, $10 \%$ ученика медицинске и 6\% ученика техничке школе. Нормалну телесну масу има (БМИ 18.5-24.9) $74.6 \%$ ученика - 71\% дечака и $78.43 \%$ девојчица, а у већем проценту су то ученици техничке школе (75.5\%). Прекомерну тежину (БМИ 25-29.9) има укупно 15.3\% ученика - 20.56\% дечака и 9.8\% девојчица. Није пронађена разлика у учесталости прекомерне тежине по школама. Гојазно (БМИ 30 и више) је 1.4\% ученика - 0.9\% дечака и 1,9\% девојчица, који су идентификовани као ученици техничке школе. Дистрибуција БМИ по старости је дата на слици 2.

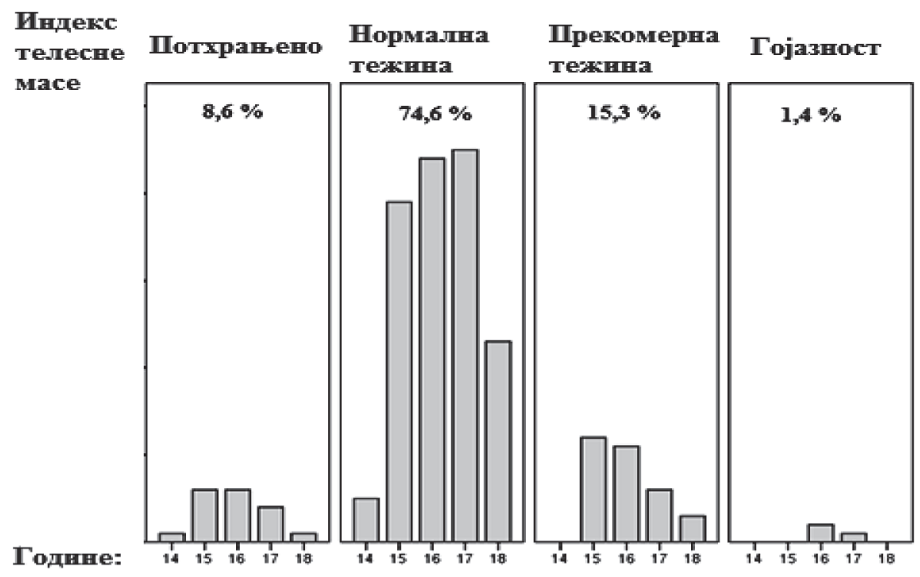

Слика 2. Индекс телесне масе $\left(\mathrm{kg} / \mathrm{m}^{2}\right)$ према узрасту

О здрављу при избору намирница за доручак увек размишља $30.1 \%$ ученика, чешће ученици медицинске (32.8\%) него техничке (26.7\%) школе. Повремено размишља $49.3 \%$ испитаника, више девојака (51\%), док 20 \% испитаника никад не размишља о здрављу при доручку, и то више мушкараца и ученика техничке школе (41\%). При ручку о здрављу увек размишља $48.3 \%$ испитаника, више ученика медицинске (53.8\%) него техничке струке (41\%), такође чешће девојчице (52\%) него дечаци (45\%).

При избору намирница за вечеру о здрављу увек размишља 40\% ученика, чешће девојчице, и ученици медицинске $(47 \%)$ него техничке школе (31\%), уз статистичку корелацију $\mathrm{p}=0.04$. У просеку $40 \%$ испитаника само повремено размишља о здрављу и избору намирница при ручку и вечери.

Физичком активношћу свакодневно се бави $32.5 \%$ испитаника, $45 \%$ дечака и $20 \%$ девојчица $(\mathrm{p}=0.01)$. Ово укључује већи део (39\%) ученика техничке школе ( $\mathrm{p}=0.04)$. Нешто ређе, 2-3 пута недељно физичком активношћу бави се $40 \%$ испитаника, углавном девојчице (44.9\%), док $15.3 \%$ скоро никада не тренира (Слика 3 ).

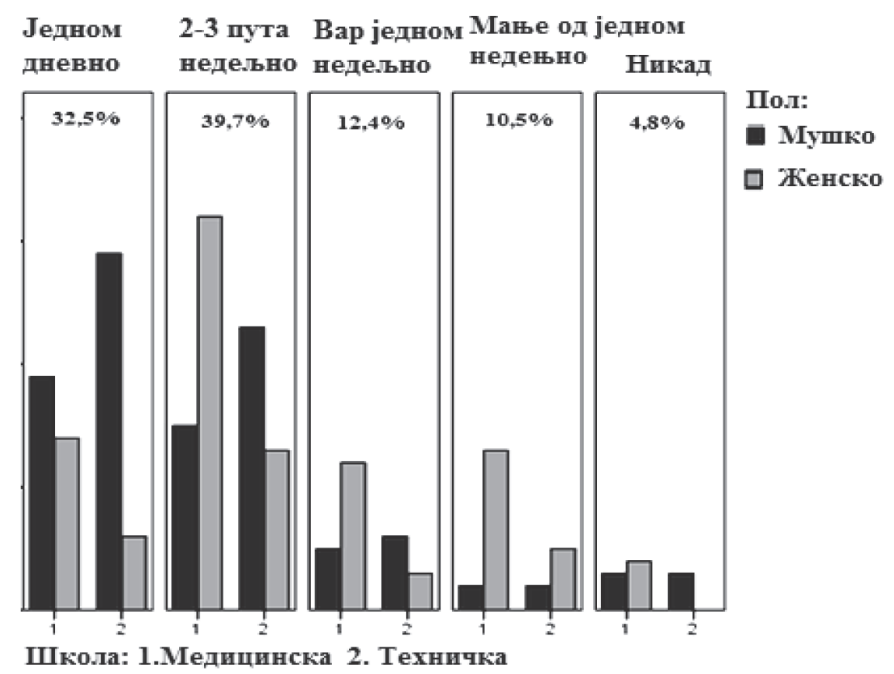

Слика 3. Учесталост физичке активности, према полу и школи 
Својим изгледом је задовољно 44\% адолесцената, $57 \%$ дечака и $30 \%$ девојчица, уз статистички значајну корелацију $p=0.01$. Једна трећина испитаника сматра да има прекомерну телесну тежину (50\% девојчица и 19.6 \% дечака), и да би требало мало смршати (Слика 4). Међу њима, $12.4 \%$ испитаника већ држи дијету, и то 15\% ученика медицинске школе и 9\% ученика техничке школе, укупно 19.6 \% од испитиваних девојчица.

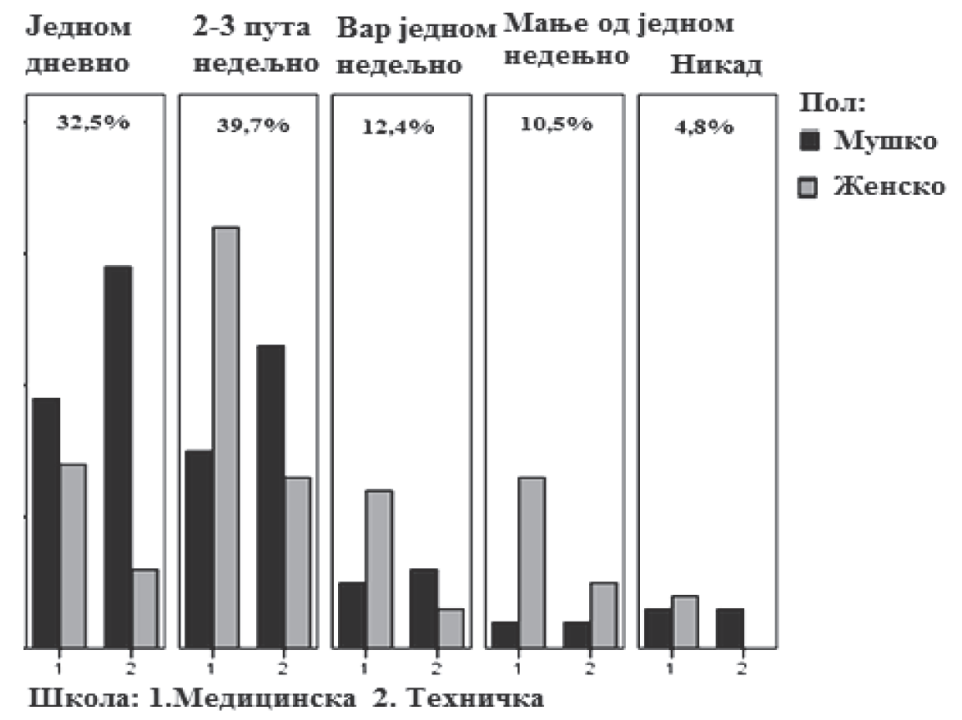

Слика 4. Мишљење испитаника о сопственој тежини, према полу и школи

Од потхрањене деце највећи број се 2-3 пута недељно бави физичком активношћу. У већем броју су свесни да су прилично мршави, и да $\delta и$ требало да се мало удебљају. Нормално ухрањени ученици такође 2-3 пута (38.5\%) и у великом броjу (32.7\%) свакодневно се ठаве физичком активношћу и задовољни су својом тежином, а поред тога 10\% њих ипак држи дијету.

Ученици са прекомерном тежином 2-3 пута (43.8\%) и свакодневно (40.6\%) се баве физичком активношћу, свесни су да имају вишка килограма, и да би требало смршати, међутим од њих само 28\% држи дијету. Позитивно је да су препознали значај свакодневне или ठар редовне физичке активности, и тако покушају да смање или одржавају тежину. Међутим, код гојазне деце примећује се да запостављају физичку активност и у већем броју баве се тиме само једном недељно (66.7\%). Неки сматрају да $\delta и$ требало мало да смршају, док има и оних који су задовољни таквом тежином. Од гојазне деце нико не држи дијету. Постоји корелација измеЂу става према сопственој тежини и индекса телене масе $(\mathrm{p}=0.00)$, као и са држањем дијете $(\mathrm{p}=0.032)($ Табела 4). 
Табела 4. Релације између индекса телесне масе и физичке активности, држања дијете и става према сопственом телу

\begin{tabular}{|c|c|c|c|c|c|}
\hline Индекс телесне масе & $\begin{array}{c}\text { Потхрањено } \\
\text { Број(\%) } \\
\end{array}$ & $\begin{array}{c}\text { Нормално } \\
\text { Број(\%) }\end{array}$ & $\begin{array}{c}\text { Прекомерно } \\
\text { Број(\%) } \\
\end{array}$ & $\begin{array}{l}\text { Гојазно } \\
\text { Број(\%) }\end{array}$ & $\begin{array}{c}\text { Укупно } \\
\text { Број(\%) } \\
\end{array}$ \\
\hline Физичка активност & & & $\mathrm{p}=0.21$ & & \\
\hline Једном дневно & $3(16.7)$ & $51(32.7)$ & $13(40.6)$ & $1(33.3)$ & $68(32.5)$ \\
\hline Два до три пута недељно & $9(50.0)$ & $60(38.5)$ & $14(43.8)$ & $0(0.0)$ & $83(39.7)$ \\
\hline Барем једном недељно & $3(16.7)$ & $19(12.2)$ & $2(6.2)$ & $2(66.7)$ & $26(112.4)$ \\
\hline Ређе од једном недељно & $2(11.1)$ & $19(12.2)$ & $1(3.1)$ & $0(0.0)$ & $22(10.5)$ \\
\hline Никад & $1(5.6)$ & $7(4.5)$ & $2(6.2)$ & $0(0.0)$ & $10(4.8)$ \\
\hline Држање дијете & & & $\mathrm{p}=0.03^{*}$ & & \\
\hline Не, задовољан/а сам телесном масом & $11(61.1)$ & $74(47.4)$ & $6(18.8)$ & $1(33.3)$ & $92(44.0)$ \\
\hline Не, али би требао/ла смршати & $1(5.6)$ & $44(28.2)$ & $16(50.0)$ & $2(66.7)$ & $63(30.1)$ \\
\hline Не, требао/ла би се угојити & $6(33.3)$ & $21(13.5)$ & $1(3.1)$ & $0(0.0)$ & $28(13.4)$ \\
\hline Да & $0(0.0)$ & $17(10.9)$ & $9(28.1)$ & $0(0.0)$ & $26(12.4)$ \\
\hline Став према сопственом телу & & & $\mathbf{p}=0.00^{* *}$ & & \\
\hline Јако мршав/а & $2(11.1)$ & $3(1.9)$ & $1(3.1)$ & $0(0.0)$ & $6(2.9)$ \\
\hline Мало мршав/a & $6(33.3)$ & $27(17.3)$ & $1(3.1)$ & $0(0.0)$ & $34(16.3)$ \\
\hline Добре телесне масе & $9(50.0)$ & $75(48.1)$ & $7(21.9)$ & $1(33.3)$ & $92(44.0)$ \\
\hline Прекомерно ухрањен/а & $1(5.6)$ & $49(31.4)$ & $21(65.6)$ & $1(33.3)$ & $7234.4)$ \\
\hline Гојазан/а & $0(0.0)$ & $2(1.3)$ & $2(6.2)$ & $1(33.3)$ & $5(2.4)$ \\
\hline
\end{tabular}

** Статистичка значајна корелација на нивоу $\mathrm{p} \leq 0.01$; ${ }^{*}$ Статистичка значајна корелација на нивоу $\mathrm{p} \leq 0.05$

\section{ДИСКУСИЈА}

Према резултатима истраживања здравља становништва Србије у 2013. години је регистрован пораст процента гојазне деце (4.9\%) у поређењу са 2006. годином (2.6\%). Такође значајно је већи проценат умерено гојазне (13.2\%) и гојазне (7.5\%) деце забележен међу децом узраста 11-14 година (Боричић и сар., 2014).

Према резултатима овог сервеја идентификовано је 16.7\% предгојазних и гојазних ученика, што упозорава на низак квалитет њихове исхране и на недовољну физичку активност. Међутим, како није детектован екстремно велики број гојазних, основна претпоставка се може одбацити.

Статус ухрањености је донекле повољнији у поређењу са истраживањем које је спроведено у Бору (централна Србија) међу основношколцима 2011. године (Станковић и Михајловић, 2011), када је показано да је нормалну телесну масу имало $81 \%$ девојчица, $3 \%$ је било потхрањено, а $16 \%$ имало вишак килограма (у овом истраживању је детектовано 9.8\% потхрањених и $11.76 \%$ девојчица са вишком килограма). Нормална телесна маса је нађена код $68 \%$ дечака, $7 \%$ је било потхрањено, а $25 \%$ са вишком килограма (у овом истраживању је детектовано 7.48 \% потхрањених и $21.49 \%$ дечака са вишком килограма).

Када је реч о школама показано је да се ученици техничке школе у већем проценту свакодневно баве физичком активношћу. Ту је идентификовано $17.8 \%$ гојазних и $6.6 \%$ потхрањених ученика, док се ученици медицинске школе ређе и у мањем броју баве физичком активношћу. Овде је идентификовано $15.9 \%$ гојазних и $10 \%$ потхрањених ученика.

Што се тиче разлике по половима, примећено је да су дечаци физички активнији, углавном задовољни својом тежином, и да само 5\% држи дијету. Девојчице, међутим, само 2-3 пута недељно се баве физичком активношћу. Скоро 50\% девојчица сматра да има вишак килограма, а $20 \%$ већ држи дијету. Својим изгледом је задовољно 44\% испитаника.

Када је реч о прекомерној тежини и узрасту детектовано је $21 \%$ петнаестогодишњака, 20.7\% шеснаестогодишњака, $12.5 \%$ седамнаестогодишњака, и $11.1 \%$ осамнаестогодишњака са прекомерном телесном тежином. Приметно, проценат прекомерно ухрањених испитаника опада са годинама старости.

Стање ухрањености адолесцената је од великог интереса за јавно здравље, са аспекта превенци- 
је болести повезаних са гојазношћу. Гојазност у овим старосним групама је често повезана са раним развојем других хроничних болести. Важно је нагласити да физичку активност код деце и адолесцената треба стално стимулисати, у чему највећу улогу имају наставници физичког васпитања.

Наставник физичког васпитања, преко својих активности у школи и ван ње, у спортским клубовима, игра важну улогу у физичком и психичком развоју деце, са видним утицајним ефектом на личност младих, непосредно помажући њиховом формирању и развијању. Наставник чини да ученици развијају кретне способности у складу са талентом, потенцијалним предиспозицијама, утичући у исто време образовно-васпитно на њихову личност (Krasniqi, Salihu, \& Ahmeti, 2008).

Неколико истраживања потврђује ову чињеницу. Тако нпр. у Индији је испитиван утицај свакодневне физичке активности ван редовних школских часова на телесни састав гојазних мушкараца узраста 9-15 година (Apte \& Rao, 2013). „Интервенција“ је подразумевала 5 тренинга недељно, ван школских часова у трајању од 50 минута. После једне школске године, проценили су утицај физичке активности на редукцију гојазности. Утврдили су да учесници показују значајне редукције телесне масти (1.0\%), редукцију дебљине кожних набора, а дошло је и до значајног смањења показатеља централне гојазности, односно обима струка (са 1.8 на $1.1 \mathrm{~cm}$ ) у односу на њихово првобитно мерење. Ово указује на то да потенцијалне користи свакодневне физичке активности од 50 минута оправдају увођење свакодневних физичких часова у наставни програм школе за боље здравље адолецената.

Међутим, бенефити редовне физичке активности могли би се достићи и у оквиру садашњег школског програма, модификацијом садржаја. То су доказали у Бразилу, када је скоро 400 испитаника старости 15-17 година укључено у истраживање о утицају физичке активности на телесни састав (Farias, Gonçalves, Morcillo, Guerra-Júnior, \& Amancio 2015). Студијска група је подвргнута специфичном програму физичке активности у току редовних часова физичког васпитања (аеробне активности, вежठе мишићне снаге, трчање, скакање, спортске игре и истезање) док је контролна група похађала конвенционални програм физичког васпитања (спортске игре кроз вежठе, гимнастика, основе спорта). Ова група је имала редовно 2 часа физичког васпитања недељно, у току школске године. У резултатима су исказани позитивни ефекти програмиране физичке активности у контролној групи ( $\mathrm{p}=0.001)$ код оба пола. Дошло је до смањења процента масти (средња разлика $=5.58 \%)$ и обима струка $(-2.33 \mathrm{~cm})$, као и пораста у чистој маси $(+2.05 \mathrm{~kg})$, а супротно је примећено у контролној групи. Ово указује на улогу наставника физичког васпитања, како самим избором телесне активности може достићи редукцију телесне тежине и допринети здрављу адолесцената у оквиру редовних наставних часова физичког васпитања.

Такође, испитиван је и утицај програмиране и самоодабране физичке активности на телесну кондицију адолесцената (Neto, et al., 2014). Једна група ученика је обављала физичку активност према сопственом ритму у следећим спортовима: кошарка, одбојка, рукомет, мали фудбал и пливање. А друга група је изводила тачно одређене активности програмиране кондиционе вежбе. Тренинзи за обе групе су трајали по 60 минута. Интервенција са програмираном физичком активношћу показала је више промене у физичким способностима, у кардиореспираторној кондицији и снагу доњих и горњих екстремитета.

Према претходно анализираном, највећи потенцијал се може наћи у решењу да друштво препозна значај превенције хроничних незаразних болести путем адекватне исхране и редовне телесне активности од најмлађег узраста. Школски спорт треба да допринесе унапређењу јавног здравља. Међутим у анализи овог проблема најчешће се наводи да постоји мали број спортских секција, које несистематично функционишу. Данас мало која школа у Србији има редовно организоване секције, па се спортом у школама редовно бави свега 3-5\% ученика, а један од основних проблема се наводи постојање свега 2 часа физичког васпитања недељно (Покрајински секретаријат за спорт и омладину, 2007).

Међутим, како се и у “Стратегијама за развој школског спорта у АП Војводини за период 20132017. године" истиче, свакодневна физичка активност би требало да буде инкорпорирана у наставни план, док се то не постигне, акценат треба ставити да спорт у основним школама буде доступан као изборни предмет, или обезбеђивањем разних спортских секција у овиру школе. 
Такође, посебан нагласак би требало стављати на школске оброке. Добре и лоше навике стечене у детињству остају до краја живота, а неправилна исхрана може оставити значајне последице. На развој прехрамбених навика школске деце највећи утицај имају родитељи, али свакако треба нагласити и утицај школе на обликовање дететове личности и усвајање навика здравог храњења и понашања.

Посебан значај има школски оброк, ужина, јер деца шест и више сати проводе у школама, и за то време конзумирају углавном нездраве оброке, грицкалице, брзу храну и газирана пића, са високим садржајем масти и концентрисаних угљених хидрата, што може да проузрокује прекомерну телесну тежину (Јанковић, 2003). Законским обезбеђивањем адекватне, здраве куване хране у школским кантинама, ученичким домовима и мензама могли би значајно допринети смањењу болести повезаних са неправилном исхраном.

\section{ЗАКЉУЧАК}

Свега трећина испитаника се бави свакодневном физичком активношћу. Разлике у начину животног стила између ученика медицинске и техничке струке, огледају се пре свега у учесталости бављења физичком акивношћу, која је у већем проценту присутна код ученика техничке школе и дечака. При процени нутритивног статуса у медицинској школи пронашли смо више потхрањених, док у техничкој школи више прекомерно ухрањених ученика. Углавном девојке су незадовољне својом тежином, те држе неконтролисану дијету. Ученици медицинске школе редовно размишљају о здрављу, али се и даље у веома малом проценту баве физичком активношћу. Очигледно, само знање које ученици добијају у медицинским школама без практичних савета и мотивације није довољно да промени начин живота. То је дуг процес који треба да започне у раном узрасту. Поред породице, школе и наставници имају кључну улогу, промовишући здраве стилова живота, значај редовне физичке активности и могуће последице гојазности.

\section{ЛИТЕРАТУРА}

1. Apte, P.P., \& Rao, S. (2013). Effects of after school physical activity intervention to reduce obesity among Indian adolescent boys. Current Research in Nutrition and Food Science Journal, 1(1): 93-101. DOI: 10.12944/CRNFSJ.1.1.10

2. Богар, Ј., Косић-Бибић, Н. (2013). Исхрана по мери средњошколаца. Хрвайски часойис за јавно зяравстиво, 9(35), 95-102.

3. Боричић, К., Васић, М., Грозданов, Ј., Гудељ-Ракић, Ј., и сар. (2014). Резултати истраживања здравља становништва Србије, 2013. година.

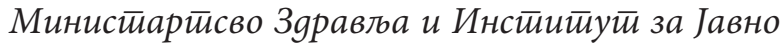
зяравлье Србије "Др Милан Јовановић-Батичй", Беoі̄pag.

4. Цвијовић, М. (2011). Значај и могућности нутритивног програма „Чиготица“ у усвајању здравог начина исхране. Сиечијална болница за

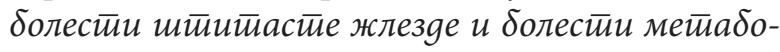
лизма, Злаииибор.16(39), 120-123.

5. Деспотовић, М., Илић, Б., Игрутиновић, 3., Марковић, С. (2013). Стање ухрањености деце предшколског узраста. Меgииински часоӣис (Країујеваи) 47(2), 62-68.

6. Farias, E.S., Gonçalves, E.M., Morcillo, A.M., Guerra-Júnior, G., \& Amancio, O.M.S. (2015). Effects of programmed physical activity on body composition in post-pubertal schoolchildren. Jornal de Pediatria (Rio J), 91(2): 122-129. DOI: 10.1016/j.jped.2014.06.004.

7. Илић, М. (2010). Навике у исхрани адолесцената у Зајечару. Тимочки меgицински іласник, 35(3-4), 57-63.

8. Јанковић, С. (2003). Пеgесеит савјетиа за здравље. Хрватски завод за јавно здравство, Загреб.

9. Krasniqi, F., Salihu, H. i Ahmeti, V. (2008). Наставник тјелесне и здравствене културе- ослонац физичког здравља и личности дјеце и младих. Sport Science, (1):66-69.

10. Лешовић, С. (2014). Центар за превенцију и лијечење претилости у дјеце и адолесцената. Paediatria Croatica, 58(1), 238-242. 
11. Маркуш, Д. (2012). Консйрукиија љьестивице за

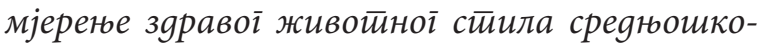
лаца. 21. љетна школа кинезиолога Републике Хрватске.

12. Наставни план. Подручје рада: Здравство и социјална заштита. Образовни профил: Медицинска сестра - техничар.

13. Neto, C.F., Neto, G.R., Araújo, A.T., Sousa, M.S.C., Sousa, J.B.C., Batista, G.R., \& Reis, V.M.R. (2014). Can programmed or self-selected physical activity affect physical fitness of adolescents? Journal of Human Kinetics, 43, 125-130.

14. Покрајински секретаријат за спорт и омлади-

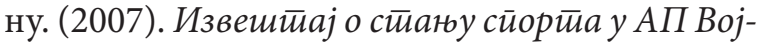
воgине. Нови Сад.

15. Станковић, Ј., Михајловић, К. (2011). Исхрана учесника осмог разреда ОШ „Љуба Нешић“. Реіионални ценіиар за йалентие, Бор, 1-12.
16. Покрајински секретаријат за спорт и омлади-

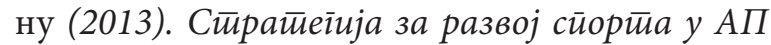
Војвоgини за йериоg 2013-2017.їодине. Нови Сад.

17. Светска здравствена организација (2005). European strategy for child and adolescent health and development. Доступно на: http://www. euro.who.int/_data/assets/pdf_file/0020/79400/ E87710.pdf (European)

18. Светска здравствена организација (2004). Food and health in Europe: a new basis for action. No.96. Доступно на: http://www.who.int/nutrition/ publications/Food_and_health_Europe $\% 20$ newbasis_for_\%20actin.pdf (European)

\title{
VERHÄLTNIS ZWISCHEN LEBENSSTIL UND ERHÄHRUNGSZUSTAND BEI ADOLESZENTEN
}

\begin{abstract}
Zusammenfassung
Der Lebensstil von Adoleszenten weckt immer größeres Interesse im Sektor der öffentlichen Gesundheit in Bezug auf die Verhinderung von Übergewicht. Das Ziel der Arbeit war es, den Lebensstil dieser Altersgruppe zu erfassen und die Unterschiede zwischen den Lebensstilen von Schülern der Medizinischen und der Technischen Schule festzulegen. Die Untersuchung wurde als Querschnittstudie während des Schuljahres 2015/2016 in der Medizinischen Schule in Novi Sad und der Technischen Schule in Subotica durchgeführt. Das Instrument der Untersuchung war ein Fragebogen, der anoynm und auf freiwilliger Basis von 209 Schülern im Alter von 14 bis 18 Jahren ausgefüllt wurde. Die Analyse der Daten wurde mit einem SPSS-Paket durchgeführt. Es wurde eine deskriptive Statistik angewendet, die statistische Bedeutung zwischen den beiden Schulen und nach den Geschlechtern wurde mit Hilfe des Pearson Chi-Quadrat-Tests geprüft. Die Schüler der Technischen Schule sind körperlich aktiver, denken aber in einem niedrigerem Prozentsatz bei der Auswahl der Lebensmittel an ihre Gesundheit; unter ihnen litten 18\% an Übergewicht. Die Schüler der Medizinischen Schule denken bei der Auswahl der Lebensmittel in größerem Maße an ihre Gesundheit, sind aber körperlich weniger aktiv, was zu einem höheren Prozentsatz (10\%) an unterernährten Schülern führte. 44\% der Prüflinge sind mit ihrem Aussehen zufrieden. Ein Drittel der Schüler ist der Meinung, dass sie eine übermäßige Körpermasse haben und abnehmen müssen. Das Wissen von der Wichtigkeit eines gesunden Lebensstils beeinflusst bei Schülern der Medizinischen Schule das Bewusstsein bei der Auswahl von Lebensmitteln und den Wunsch, das eigene Gewicht zu kontrollieren, hat aber keinen Einfluss auf die Regelmäßigkeit von körperlichen Aktivitäten.
\end{abstract}

Schlüsselwörter: KÖRPERLICHE AKTIVITÄT / DIÄT / GESUNDHEIT / LEBENSMITTEL

Примљен: 05. 02. 2017. Прихваћен: 17. 11. 2017. 